\title{
For Inclusive and Sustainable Education: The Profile of the Educator and Pedagogist in Italy
}

\author{
By Amelia Lecce ${ }^{*}$ and Paola Aiello
}

\begin{abstract}
The changes that have characterized contemporary complex societies and the need to affirm the values of social inclusion have led the Italian educational policy makers to debate on the professional quality within the educational field, to study its changes and its social impact. This debate has gradually led to a redefinition of the professional profile of the educator and the pedagogist giving rise to a legislative provision aiming at recognizing, regulating and protecting these professionals. According to this law, in particular, the socio-pedagogical educator and the pedagogist are required to have specific competences that could promote inclusive and sustainable educational actions. The present theoretical argumentative paper aims at presenting a synthesis of the long debate that led to the approval of Law 205/17 in Italy, involving policy makers and Italian scholars and academics in the redefinition of the educational professions. Specifically, it aims at highlighting the rational and the characteristics of the context which have supported the long legislative process within a conceptual dimension that considers inclusive education as an unavoidable framework for social sustainability.
\end{abstract}

Keywords: inclusive education, sustainable education, educator and pedagogist, Italy

\section{Introduction}

The present theoretical paper represents the synthesis of a long debate aimed at the realization of a Reform in Italy on the education professions. Indeed, starting from 2017, political decision makers and representatives of the Italian academic world have redefined the role of the education professions (Law 205/17) ${ }^{1}$.

The changes that have characterized contemporary complex societies and the need to affirm the values of social inclusion have conducted the Italian educational policy makers to question themselves about the professional quality of the educational field, to study the changes and the effects on a social level. The norm has redefined the professional profile of the educator and the pedagogist by regulating and preserving the profession.

In particular, according to this law, the socio-pedagogical professional educator and the pedagogist are required to have specific skills to carry out activities that take into account the specificity of the profession and the social and inclusive function of an education that can be defined sustainable (Sterling 2006).

\footnotetext{
"PhD Student, Department of Humanities, Philosophy and Education, University of Salerno, Italy. ${ }^{ \pm}$Professor, Department of Humanities, Philosophy and Education, University of Salerno, Italy.

${ }^{1}$ Legge 205/17, commi 594-601. Gazzetta Ufficiale n. 302 del 29.12.2017. Entrata in vigore 1.1.2018.
} 
The inclusive function of education lies in thinking in terms of valorizing personal multiplicity, beyond any form of "labeling" and "stigmatization" (Aiello 2018). Indeed, if the label "establishes a sense, a sort of order of the wearer" (Benasayag and Schmit 2004, p. 75), inclusive education aims at eradicating such thinking and believing in the educability of "each and every one" (European Commission 1996). Therefore, believing in "Education for All" (UNESCO 2000) means supporting the principle of equal opportunities and encouraging policies to promote the participation of each individual citizen in society.

An inclusive educational approach is based on the recognition of individual differences as an opportunity for subjective and collective enrichment (Sibilio and Aiello 2015), where difference is considered a fundamental right of expression of each individual (Sen 2008). Indeed, the education professions are characterized by competence in approaching problems, but also attention to the personal, social and ethical sphere (Sibilio and Aiello 2018).

The different educational contexts (school-family - digital education educational services - adult education - teacher training) (Riva 2018) are the contexts where the "alliance" between education and society for "sustainable participation" is enhanced (Riva 2018, Sterling 2013).

In the light of the new professional profile and the change of perspective of the welfare systems (Donati and Solci 2011, Giddens 2001) it seems appropriate to think about the skills of the educator and the pedagogist by identifying in the knotworking (Engeström 1995, 2000, 2008, Engeström et al. 2012) a possible model of application.

\section{The Professional Recognition of Educators in Italy}

In Italy, the professions of the educator and the pedagogist, today, appear strategic in the perspective of an indispensable innovation of the welfare system, according to a promotional and regenerative approach (Iori 2018). Although for a long time these figures have been seen as professionally weak (Glazer 1974) because they derive from a weak knowledge (Iori 2018), they have been strongly defended by the world of professional and student associations that have claimed the urgency of a new professional dignity.

Within the Italian context, the need to generate a new welfare system has led to the definition of new profiles of professional skills. Indeed, the professional profile is structured on the basis of the implementation of actions of support, exchange, enhancement of the characteristics and resources of each person (Iori 2018). The law aims to create new virtuous circuits where citizens recognize themselves as communities and encourage assistance, support, exchange and promotion of the resources present in each person. The beneficiary of a service is not simply a citizen (seen as a passive user of a service), but an active protagonist and generator of a new system of regenerative welfare.

Indeed, the law on the professional recognition of educators is affected by the diachronic and synchronic dimension of education (Scurati 1986) conveying a new educational message that allows a change of perspective of the welfare 
system $^{2}$ (Fiorentini 2006, 2016, Fiorentini and Calò 2013).

In Italy, in the period prior to the reform, there was no higher education requirement for the profession and therefore everyone could work as an educator (Iori 2018). The law recognizes more than one hundred thousand educators and pedagogists working on the national territory, but also protects those who carry out work without an academic title, providing a university training course to obtain 60 university credits useful for the equivalence of the three-year degree. The intensive training course to acquire the 60 university credits is tailored on those who have already passed a national examination related to the profile of educator, on those who have worked as educator for at least three years and on those who have a qualifying diploma issued within the 2001/2002 school year from an institute or a magisterial school (L. 205/17).

Indeed, Italian universities, in compliance with paragraph 597 of the aforementioned law, are preparing for the introduction of an intensive course in the socio-psycho-pedagogical disciplines.

For this reason, in line with European and international guidelines, a reform has been implemented in Italy to regulate the professions of Educator and Pedagogist. The reform ensures homogeneous services and adequate educational interventions throughout the country according to the needs of the population.

With the law 205/17, the socio-pedagogical professional educator is involved in educational and training activities dedicated to the planning, implementation and evaluation of educational and training interventions and treatments directed at the person in the areas and services.

The educator becomes a companion and facilitator of the learning processes in the contexts of lifelong learning and professional training, as well as trait d'union in favor of job placement. Finally, he is recognised as a mediator in the definition of training policies, planning and management of network services in the territory in a collaborative vision for the activation of integrated systems for the management and enhancement of resources (Disegno di legge, n.2443) ${ }^{3}$.

According to the European Qualifications Framework (EQF) ${ }^{4}$ ranking, the socio-pedagogical professional educator, after the degree course in Education (L19) should have acquired:

\footnotetext{
${ }^{2}$ The welfare state is a set of public policies that participate in the process of modernizing a state. Through these measures, the State provides its citizens with protection against risks and guarantees them pre-established needs, in the form of assistance, insurance or social security. It introduces, among other things, specific social rights as well as specific financial contribution duties. The four main actors of the welfare state are: State; family; market; third sector (Ferrera 1993).

${ }^{3}$ Senato della Repubblica Italiana, Disegno di Legge (Delega per la riforma dell'organizzazione del Governo e della Presidenza del Consiglio dei ministri [Disciplina delle professioni di educatore professionale socio-pedagogico, educatore professionale socio-sanitario e pedagogista]), n. 2443. XVII Legislatura, 21 giugno 2016.

${ }^{4}$ The QEF is a European certification able to make professional qualifications homogeneous in different European countries with the aim of comparing education and training. The classification ranges from level 1, which is equivalent to the achievement of compulsory schooling, to level 8 , which corresponds to the highest level with the acquisition of the title of research doctor or equivalent (European Commission 2009). The socio-pedagogical educator is part of the $6^{\text {th }}$ level of the EQF. The educator, on the other hand, is part of the $7^{\text {th }}$ level of the QEF.
} 
- advanced knowledge of theories and principles useful in workplace or study;

- advanced problem-solving skills;

- technical and professional skills in team management.

The qualification of pedagogist is obtained by earning a master's degree in Design and management of educational services (LM-50), Adult and Lifelong Education (LM-57), Pedagogy (LM-85), Theories and methodologies of elearning and media education (LM-93) (L. 205/17).

The pedagogist carries out activities of design, planning, organization, coordination of territorial educational and training services, management, monitoring, evaluation, consulting and supervision of the pedagogical quality of public or private educational and training systems. It also carries out pedagogical actions addressed to single individuals. The pedagogist should have:

- highly specialized theoretical knowledge able to solve problems within a specific field;

- problem solving skills to be implemented through the exchange of knowledge from different disciplinary fields;

- strategic competence in the management of complex work or study contexts.

The recognition of the new professional identity acknowledges that the educator plays a central role as a promoter of active and responsible citizenship (Council of Europe 2010). The reform in favor of educators shifts the debate on the principle of sustainability by promoting the adoption of behaviors and attitudes that respect people, the environment, the individual, local and global communities (Chiappetta Cajola 2018).

Therefore, the educational difficulty consists in formulating effective intervention models, able to significantly affect future generations. For this reason, the educational intervention should tend to create opportunities and conditions that aim at improving the quality of life ${ }^{5}$.

\section{The Sustainable Educator}

The World Commission on Environment and Development (Commissione Bruntland 1987) was the first to introduce the concept of sustainable development.

In the document Our Common Future, also known as the Brundtland Report (after the Norwegian Prime Minister Gro Harlem Brundtland, then president of the WCED), "sustainable development is a form of development that meets the needs of the present without compromising the ability of future generations to satisfy

\footnotetext{
${ }^{5}$ The concept of quality of life assessment was introduced for the first time in Italy by the Finance Act 163/2016, which speaks of BES (Benessere Equo e Sostenibile) (Santerini 2018). This concept is based on the idea that the quality of life of individuals cannot be based only on the increase in wealth, but also on the acquisition of human rights, on laws in favor of inequalities, on the autonomy of women (Stiglitz et al. 2013).
} 
their own" (Commissione Bruntland 1987). This definition highlights the ethical responsibility of current productively active generations towards future generations.

Nowadays, the term sustainability is too often used in a generic, often improper way. It is used as an adjective to describe nouns such as development, tourism, company, etc., implicitly considering this word to refer to environmental sustainability, when, in reality, it is not so. Indeed, there are many and more complex aspects concerning the sustainability profile of human interventions on the territory and on the environment, keeping in mind that these terms are not synonymous: if the territory is a physical space on which typical human activities take place such as traditions, culture, etc., the environment is the location in which the individual resides. Surely environmental sustainability cannot be considered separately from economic, financial or social agendas. Therefore, global sustainability is connected to safeguarding the environment, defending local identities and the real feasibility of projects that respond to a territorial vocation (Forlani 2010).

It deals with the possibility of considering sustainability as a synergic system that embraces multiple fields of action: from the environment to culture, from education to the economy and from society to Corporate Social Responsibility ${ }^{6}$ (Bandini and Ambrosio 2012, Bandini 2015, Maloni and Brown 2006).

There are different kinds of sustainability: for example, in the economic sphere, a company is truly sustainable if it is able to set its own business strategy harmoniously combining the "3Ps": Profit, Planet, People (Elkington 1997, 1999, 2004).

A sustainable society is a society that believes in future generations, which looks ahead, which is flexible and wise, (Sterling 2013, Sennet 1999), which recognizes that ecological, social, ethical and economic aspects as extremely valuable, precisely because they are all interconnected, opening useful passages to new types of knowledge and new collaborative forms.

This assumption demonstrates the impossibility of disconnecting the various disciplinary fields from an ecological and sustainable perspective, where it is necessary to work on the medium and not on the aim, on the path to take and not only on the result.

The current educational challenge is precisely to face complexity through alternative actions or models reflecting on sustainability in general and educational sustainability in particular (Malvasi 1995).

Education is a conditio sine qua non to create a more sustainable and more

\footnotetext{
${ }^{6}$ The Lisbon European Council, in March 2000, identifies Corporate Social Responsibility (CSR) as a best practice to follow to improve employment and social cohesion. CSR has now become a widespread practice in the new millennium (Pedersen 2006) and is considered an effective strategy for creating a competitive and socially cohesive society.

The CSR identifies virtuous practices and behaviors that a company can adopt, it also seeks to obtain results that can bring benefits and advantages to itself and to the context in which it operates. Particular attention is paid to relations with its stakeholders: stakeholders, suppliers, customers, partners, communities and local institutions, realizing concrete actions towards them. This translates into the adoption of a company policy that is able to reconcile the economic objectives with the social and environmental objectives of the reference area, with a view to future sustainability (Bandini and Ambrosio 2012, Bandini 2015).
} 
peaceful world, though this requires a necessary shift in thinking. The quality, intensity and level of learning that takes place on a global scale over the next ten or twenty years will determine the action to take: the one that leads to ecological sustainability or the one that moves away from it (Sterling 2013, Sterling 2009).

To re-establish education in a sustainable perspective, we need to look beyond the world of education, which often appears too closed, and try to open up to the different disciplinary fields that focus on the quality of life of human beings: sustainable education can only emerge if it can connect and draw strength from a positive cultural change in a social context. The roots of a new post-modern educational paradigm must be found in many "growth areas" converging within an enlarged society, which somehow reflects systemic thinking: revisionist postmodernism, the ecological movement and the corresponding view of the world, the science of complexity, participatory and ecological democracy, the theory and practice of ecologically sustainable development (Sterling 2013).

In 1998, in England, a working group for the Government Commission on Education for Sustainable Development produced an essential document for educators who should know how to operate in terms of sustainability. The key concepts for a sustainable education are certainly the interdependence of disciplines and knowledge (characterized by a continuous exchange between society, economy, environment and from local to global aspects); participation in active and responsible citizenship; the promotion of differences as an added value of a community and from promotion of the quality of life and respect for the environment.

In the light of these key points, Sterling (2013) has developed his reflection on sustainable education, introducing a tripartite model characterized by three types of educational qualities: extensive, connective, integrative.

Sustainable education is extended when:

- it enhances the uniqueness and potential of each individual or group, bringing out the qualities of each environment and considers personal and local knowledge to be of fundamental importance for learning;

- it adopts ethical principles by extending the concept of care from society to nature in a future perspective;

- it transforms a theory into a new practice in the various educational fields;

- it adopts the human holistic capacity, related to the person's need for learning, understood in its totality, by different individuals and groups;

- it adopts epistemic principles, because it is aware of its own way of seeing the world and of the basic values that are reviewed and critically examined;

- it orients its purpose to the future as it projects its gaze of interest to the future;

- it orients values with the intention of producing beneficial changes for all of humanity.

Education is connective when it is:

- contextual, in the sense that it adheres to the real world because it responds 
to its needs;

- re-centered, in the sense that it hopes for a sustainable lifestyle by linking human and natural ecology, social equity and the future;

- critical and ideologically aware;

- relational, in the sense that it connects the models of change, in the various disciplinary areas, in the local-global, past-present-future, personal-social, environmental-economic, human-natural perspective;

- pluralistic, in the sense that it reflects and evaluates the multiple modes of knowledge;

- multi and trans-disciplinary, with reference to various areas of knowledge are not delineated by boundaries allowing for collaboration in the face of complex issues.

Education is integrative when it is:

- process-oriented, in the sense that "it builds meanings through a process of learning based on involvement and participation, which includes different learning styles. We are all learners, including teachers and officials "(Sterling 2013, pp. 107-108);

- balanced, in the sense that it takes care of the individual as a whole, respecting the affective and cognitive sphere, the objective and subjective dimension and the personal and collective level;

- inclusive, referring to each individual for the duration of their life;

- synergetic, in the sense that it plans curricula, organization, management and culture to develop reciprocally (Sterling 2013);

- open and inquiring, stimulating curiosity, intuition, creativity;

- various, in the sense that it recognizes the different ways of teaching and learning;

- a learning community, in the sense that communities must actively participate in the construction of meaningful and reflective learning that respond to a systemic approach;

- autonomous in in the organization, in the sense that it activates processes of subsidiarity and active and participatory democracy (Cfr. Sterling 2013, pp. 106-108).

Sterling's assumptions are fundamental to initiate a systemic and logical process of change towards sustainable education for communities and their members. Furthermore, a sustainable educator gives value to the people of a given community and recognizes their strengths, since he believes that every individual has the potential to act directly on the educational system.

Therefore, the educator becomes the promoter of a profitable communication between the individuals involved in the educational process, as collaboration always represents a moment of professional growth. The sustainable educator creates solid network agreements with the local authorities, recognizing the importance of teamwork in implementing projects that have a transformative value for the territory. Additionally, the educator identifies possible alliances both inside 
and outside the working environment, through personal contacts or through websites that deal with Education for Sustainable Development ${ }^{7}$.

\section{The Educator's Project Design Skills}

Law 205/2107 encourages flexible and sustainable educational actions; qualities that affect the construction of strong relationships between the various actors of the Third Sector. Therefore, the educator becomes a real agent of change, a professional who has all the skills to act in a transformative way on the system. The professional educator could have a positive impact on welfare as she/he knows the real needs of the users and the functioning of the institutions. Indeed, the aim of the educational action is not only the output, but also the outcome and the impact of that action ${ }^{8}$.

These reflections are conceptually linked to the Third Sector Reform, initiated with law 117/2017, which recommends, among other innovations, the adoption of the social impact assessment of the activities carried out. ${ }^{9}$

For this reason, it is necessary to promote the design competences of the educator and the pedagogist.

A competence is the integrated and harmonious synthesis of knowledge, knowing how to be and knowing how to act (Pellerey 2004). Within educational services, design competence is the combination of the operator's technical ability and experience. The good educator knows how to control variables, adopting the principles of flexibility, innovation and sustainability (Traverso 2018, 2011).

An effective educational project should be organized in four areas:

- personal area, as it examines the subjective conditions of the related behaviours;

- social area, as it concerns the commitment of the individual to a Community commitment perspective;

- spatial area, as it affects the relations between the various actors involved;

- temporal area, as it can be placed and sustained over time (Cfr. Santerini in Sclaunich et al. 2010, pp. 89-93).

An educational project should consider the individual not as a single unit, but as part of a heterogeneous whole in which the singularities of each are respected

\footnotetext{
${ }^{7} \mathrm{~A}$ website that aims to promote sustainable education is http://asvis.it/educazione-allo-svilupposostenibile/.

${ }^{8}$ The term outcome refers to all observed changes (expected, unexpected, positive and negative) in the recipient, in the short, medium and long term. Impact is defined as "correct outcomes". Effect and impact are synonymous, while outcome expresses the change observed (Ferri et al. 2016).

${ }^{9}$ The Non-Profit sector in Italy is made up of voluntary organisations, social promotion associations, philanthropic organisations, social enterprises, associative networks, mutual aid societies and any other body (association or foundation) that pursues civic, solidarity and non-profit social utility aims. With the approval of the Third Sector Reform, we are trying to put order in the Italian "nonprofit" world. One of the objectives of the Reform is the promotion of active citizenship, cohesion and social protection, in accordance with the principle of subsidiarity (Pagamici 2017).
} 
and enhanced (Santerini in Sclaunich et al. 2010).

\section{A Possible Model for the Promotion of Sustainable Education: Knotworking}

To achieve specific educational goals, the educator should develop mediating skills, but working in groups composed of different professionals often seems to be complicated.

One can say that non-profit is an island with few bridges. This metaphor is intended to underline the difficulty of building significant relationships with the whole economic, social and educational field. Therefore, the educator and the pedagogist could become incisive and pioneering to facilitate this dialogue. For this reason, it is possible to find in knotworking a possible model for orienting educational activity in the complex interweaving of professional relationships.

In these years, pedagogy has focused its attention on the analysis of the educational action in different life contexts by introducing the concept of an integrated training system.

The integrated training system is a model that is based on the evolution of the meaning of the territory and the local community that goes beyond the physicalgeographical meaning and that is interested in the productive, social, educational, family and associative dimensions.

There is an evolution of the spatial paradigm in favor of a relational paradigm that studies the relationship between educational agencies and resources (Perla and Riva 2016).

Within this theoretical scenario, knotworking could represent a possible model for the promotion of sustainable education. The studies on the knotworking model were developed at the Center for Activity Theory of the University of Helsinki, by Engeström and his collaborators. This model was developed to understand the organization of educational contexts and to promote the intervention of educators (Engeström 2000, Engeström et al. 2012, Kerosuo 2015). It is rooted in activity theory and in the theoretical framework developed by Vygotsky, Leont'ev, Rubinstein and Luria, who affirm that there is a close link between social actions and the cultural system of reference. The "product", indeed, is the consequence of a mediation between the "tools", a "subject" and an "object" (Zucchermaglio 1996). Today, thanks to the studies of Engeström, the activity theory has been expanded to be more functional to the demands of the new forms of work organizations "for require negotiated 'knotworking' across boundaries. Correspondingly, expansive learning increasingly involves horizontal widening of collective expertise by means of debating, negotiating and hybridizing different perspectives and conceptualizations" (Engeström 2000, p. 960).

The context in which the educational activity takes place, according to the Activity Theory, is oriented to the process and sharing of significant relationships (Rivoltella 2003). Today, the relationships and the context are characterized by physical environments, social relationships, languages, media, technological devices, artifacts, etc. (Rivoltella and Rossi 2017).

A knotworking consists of a group of people who converge and share an 
educational process in a specific space-time trajectory (Bonometti 2008). Some moments are characterized by more intense activities, others, instead, need to establish weak ties to make the tension loosen. The prerogative is to establish a web of relationships in a given period of time so that a shared result can be achieved, through negotiation processes (Perla and Riva 2016).

Therefore, knotworking is not only a model of interaction between several actors engaged in a project, but it can become an opportunity for learning and growth for the professionals involved in the action.

Engeström, based on the theory of expansive learning develops the Change Laboratory process (Engeström et al. 1996, Virkunnen 2013). The Change Laboratory is based on three main moments: Agreement; Boundary Crossing; Multi-Voice Dialogue (see Figure 1). The Agreement highlights the need to overcome one's own cultural, methodological and professional boundaries; Boundary Crossing brings out border areas from which new skills and innovations emerge; Multi-Voice Dialogue enhances feedback and dialogue between professionals and ends with negotiation as a way to proceed (Engeström 2000, 2008 in Perla and Riva 2016).

Figure 1. Main Moments of Knotworking

\begin{tabular}{|c|c|}
\hline Knotworking & $\begin{array}{l}\text { - consists of a group of people who converge and share an } \\
\text { educational process in a specific space-time trajectory }\end{array}$ \\
\hline 1. Agreement & $\begin{array}{l}\text { highlights the need to overcome one's own cultural, } \\
\text { methodological and professional boundaries }\end{array}$ \\
\hline 2. Boundary crossing & $\begin{array}{l}\text { brings out border areas from which new skills and innovations } \\
\text { emerge }\end{array}$ \\
\hline 3. Multi-Voice & - enhances feedback and dialogue between professionals and \\
ends with negotiation as a way to proceed
\end{tabular}

The intervention promotes collaborative actions (knowledge spiral) and networking among professionals in order to facilitate the learning process of all.

In this sense, knotworking can be viewed as networking and teamwork among diverse professionals whose goal is the educational success of individuals with educational needs (Engeström 2008). The model is useful in complex educational contexts, where often the figure of the educator collaborates with other professionals of the field, such as teachers, social services operators, doctors. The educator and pedagogist could find in knotworking a possible inclusive educational model to be used during his/her professional work.

Indeed, knotworking is an inclusive model because it aims at promoting learning processes. Learning in broader cultural contexts therefore requires a competence in planning, programming, organising and coordinating territorial educational services, that is perfectly in line with the profile outlined for educators and pedagogists. 


\section{Conclusion}

Thinking in terms of sustainability produces important benefits in educational, social and economic terms because it develops and supports the inclusive model, where each subject feels valued based on the influence he/she has of acting on the world. Adopting a sustainable perspective is a revolution in the way of thinking of citizens and educational figures because it has implied in its educational action a critical, relational, autonomous, participatory competence in democratic rights and responsibilities.

Sustainable education stimulates interdependent relationships among society, economy and the natural environment at all levels - from local to global, in a logic of acceptance of cultural differences - empowering the idea that an inclusive society is "possible and necessary". In this sense, the principle of Education for All is the promoter of an educational policy aimed at identifying educational methods.

In the light of what has been said so far, we can define the figure of the educator and pedagogue, as expressed in Law 205/17, as having a sustainable orientation, because it has implicit in its educational action an inclusive value that recognises the individual peculiarities of each individual and acts in order to promote them. Reasoning on the design skills of new professionals means structuring ad hoc university courses, functional to a process-oriented work vision.

Indeed, the law 205/17 suggests a professional profile competent in the exploitation of individual and collective resources. In fact, the Law 205/17 suggests a competent professional profile in the enhancement of individual and collective resources through more integrated and flexible teamwork.

In the wake of these reflections, it is possible to find in the Engeström's knotworking model a possible guideline to facilitate the complex educational work, make it more flexible, networking it with the various professionals, within a sustainable perspective.

\section{References}

Aiello P (2018) Ronald Gulliford. Alle origini del concetto di bisogno educativo speciale (Ronald Gulliford. The origins of the concept of special educational needs). Milano: Franco Angeli.

Banbini F (2015) Economia e management delle aziende non profit e delle imprese sociali, (Economics and management of non-profit and social enterprises). Lavis: CEDAM.

Bandini F, Ambrosio G (2012) Profit-Non profit una partnership di valore (Profit-Non profit a valuable partnership) Milano: Franco Angeli.

Benasayag M, Schmit G (2004) L'epoca delle passioni tristi (The age of sad passions). Milano: Feltrinelli.

Bonometti S (2008) Apprendere nei contesti di lavoro, prospettive pedagogiche per la consulenza formativa (Learning in work contexts, pedagogical perspectives for training counselling). Macerata: EUM.

Chiappetta Cajola L (2018) Scuola \& università: fare sistema e creare sinergie per il piano di educazione alla sostenibilità (School \& university: working together and creating 
synergies for the Sustainability education plan). Pedagogia Oggi/Rivista SIPED $\mathrm{XVI}(1)$.

Commissione Bruntland (1987) Our common future: the world commission on environment and development. Oxford: Oxford University Press.

Council of Europe (2010) Carta Europea sulla Educazione per la Cittadinanza Democratica e l'Educazione ai Diritti Umani (Map of Europe on Education for the Democratic Citizenship and Education by Diritti Umani). Council of Europe.

Donati P, Solci R (2011) I beni relazionali: che cosa sono e quali effetti producono (Relational goods: what they are and what effects they produce). Torino: Bollati Boringhieri.

Elkington J (1997) Cannibals with forks: the triple bottom line of $21^{\text {st }}$ century business. Oxford: Capstone.

Elkington J (1999) Triple bottom-line reporting: looking for balance. Australian CPA 69(2): 18.

Elkington J (2004) Enter the triple bottom line. In A Henriques, J Richardson (eds.), The Triple Bottom Line: Does it All Add Up? Assessing the Sustainability of Business and CSR, 1-16. London: Earthscan Publications.

Engeström Y (1995) Poly-contextuality and boundary crossing in expert cognition: learning and problem solving in complex work activities. In Learning and Instruction v, 4: 319-336.

Engeström Y (2000) Activity theory as a framework for analyzing and redesigning work. In Ergonomics XLIII, 7.

Engeström Y (2008) From teams to knots activities- theoretical studies of collaboration and learning at work. New York: Cambridge University Press.

Engeström Y, Virkkunen J, Helle M, Pihlaja J, Poikela R (1996) The Change laboratory as a tool for transforming work. Lifelong Learning in Europe 1(2): 10-17.

Engeström Y, Kaatrakoski H, Kaiponen P, Lahikainen J, Laitinen A, Myllys H et al. (2012) Knotworking in academic libraries: two case studies from the University of Helsinki. Liber Quarterly 21(3-4).

European Commission (1996) La Carta di Lussemburgo (The Charter of Luxembourg). Bruxelles: European Commission.

European Commission (2009) Quadro europeo delle qualifiche per l'apprendimento permanente $(E Q F)$ (European framework of qualification for permanent access (EQF)). Lussemburgo: Ufficio delle pubblicazioni ufficiali delle Comunità europee.

Ferrera M (1993) Modelli di solidarietà: politica e riforme sociali nelle democrazie (Models of solidarity: Politics and social reform in democracies). Bologna: Il Mulino.

Ferri P, Colombo GM, Giovine E, Ilari C, Leone L, Postacchini P, et al. (2016) Riforma del terzo settore: profili innovativi e applicativi della Legge delega (Reform of the third sector: innovative profiles and application of the enabling act. Assago: IPSOA.

Fiorentini G (2006) Impresa sociale e sussidiarietà (Social enterprise and subsidiarity). Milano: FrancoAngeli.

Fiorentini G (2016) Il welfare universalistico a sussidiarietà variabile (WUSV) $e$ il modello "la dote e la rete" (Universalist welfare with variable subsidiarity (WUSV) and the "dowry and network" model). Istituti di Ricerca sull'Impresa Sociale.

Fiorentini G, Calò F (2013) Impresa sociale \& innovazione sociale: imprenditorialità nel terzo settore e nell'economia sociale: il modello IS\&IS, (Social enterprise \& social innovation: entrepreneurship in the third sector and social economy: the IS\&IS model). Milano: Franco Angeli.

Forlani MC ( 2010) Cultura tecnologica e progetto sostenibile (Technological culture and sustainable design). Firenze: Alinea Editrice. 
Giddens A (2001) La terza via (The third way). Milano: Il Saggiatore.

Glazer N (1974) Schools of the minor professions. Minerva 12(3): 346-364.

Iori V (2018) Educatori e pedagogisti.: senso dell'agire educativo e riconoscimento professionale (Educators and pedagogues: sense of educational action and professional recognition). Trento: Erickson.

Kerosuo H (2015) BIM-based collaboration across organizational and disciplinary boundaries through knotworking. Procedia Economics and Finance 21(May): 201208.

Maloni M, Brown M (2006) Corporate social responsibility in the apply chain: an application in the food industry. Journal of Business Ethics 68(1): 35-52.

Malvasi P (1995) Etica e interpretazione pedagogica (Ethics and pedagogical interpretation). Brescia: Editrice La Scuola.

Pagamici B (2017) Impresa ibrida e terzo settore (Hybrid enterprise and the third sector). Milano: Primiceri Editore.

Pedersen ER (2006) Making corporate social responsibility (CSR) operable: how companies translate stakeholder dialogue into practice. Business and Society Review 111(2): 137-163.

Pellerey M (2004) Le competenze individuali e il portfolio (Individual competences and the portfolio). Milano: Etas.

Perla L, Riva MG (2016) L'agire educativo (Educational action). Milano: Editrice La Scuola.

Riva MG (2018) Sustainability and participation: an educational challenge. Pedagogia Oggi/Rivista SIPED XVI(1).

Rivoltella PC (2003) Costruttivismo e pragmatica della comunicazione on line (Constructivism and pragmatics of online communication). Trento: Erikson.

Rivoltella PC, Rossi PG (2017) L'agire didattico: manuale per l'insegnante (Teaching action: handbook for teachers). Brescia: La Scuola.

Santerini M (2018) Sustainable education and justice in education. Pedagogia Oggi/ Rivista SIPED XVI(1).

Sclaunich M, Feresin C, Mocinic S (2010) Lo sviluppo sostenibile: il panorama educativo italiano all'interno della prospettiva europea (Sustainable development: the Italian educational landscape within the European perspective). Pedagogika.it. XIV: 89-93.

Scurati C (1986) L'educazione extrascolastica: problemi e prospettive (Out-of-school education: problems and perspectives). Brescia: La Scuola.

Sen A (2008) Identità e violenza (Identity and violence). Bari: Laterza.

Sennet R (1999) L'uomo flessibile: le conseguenze del nuovo capitalismo sulla vita personale (Flexible man: the consequences of the new capitalism on personal life). Milano: Feltrinelli.

Sibilio M, Aiello P (2015) Formazione e ricerca per una didattica inclusiva (Training and research for inclusive education). Milano: Franco Angeli.

Sibilio M, Aiello P (2018) Lo sviluppo professionale dei docenti: ragionare di agentività per una scuola inclusiva (Teachers' professional development: reasoning about agentivity for an inclusive school). Napoli: Edises.

Sterling S (2006) Educazione sostenibile (Sustainable education). Cesena: Anima Mundi Editrice.

Sterling S (2009) Sustainable education. In Science, Society and Sustainability: Education and Empowerment for an Uncertain World, 105-118.

Sterling S (2013) Educazione sostenibile (Sustainable education). Cesena: Anima Mundi.

Stiglitz JE, Sen AK, Fitoussi J-P (2013) La misura sbagliata delle nostre vite: perché il PIL non basta più per valutare benessere e progresso sociale (The wrong measure of 
our lives: why GDP is no longer enough to measure well-being and social progress) Milano: Rizzoli ETAS.

Traverso A (2011) Progettare l'educazione: contesti, competenze, esperienze (Designing education: contexts, competences, experiences. Milano: Franco Angeli.

Traverso A (2018) Metodologia della progettazione educativa: competenza, strumenti e contesti (Methodology of educational design: competence, tools and contexts). Roma: Carrocci Editore.

UNESCO (2000) Education for all: meeting our collective commitments. Notes on the Dakar Framework for Action. Paris: UNESCO.

Virkkunen J (2013) The change laboratory: a tool of collaborative development of work and education. Rotterdam, Boston, Taipei: Sense Pubblischers.

Zucchermaglio C (1996) Vigotskij in azienda: apprendimento e comunicazione nei contesti lavorativi (Vigotsky in the company: learning and communication in working contexts). Roma: Carocci Editore. 